\title{
Perlindungan Hukum Terhadap Terumbu Karang di Taman Nasional Taka Bonerate (TNT)
}

Oleh: Zulkifli Aspan ${ }^{1}$

\begin{abstract}
Abstrak
Taman Nasional Taka Bonerate (TNT) adalah taman laut dengan kawasan atol terbesar ketiga di dunia setelah Kwajifein di Kepulauan Marshall dan Suvadiva di Kepulauan Maladewa. Luas total dari atol ini 220.000 hektare dengan sebaran

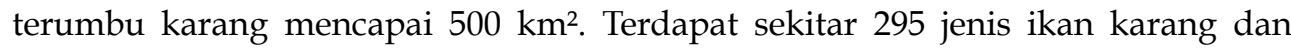
berbagai jenis ikan bernilai ekonomis tinggi seperti Kerapu (Epinephelus spp.), Ikan Naopoleon (Cheilinus undulatus), dan Baronang (Siganus sp). Sebanyak 244 jenis moluska di antaranya Lola (Trochus niloticus), Kerang Kepala Kambing (Cassis cornuta), Triton (Charonia tritonis), Batulaga (Turbo spp.). Penelitian ini bertujuan memberikan perlindungan hukum terhadap ekosistem terumbu karang di TNT. Metode peneltian bersifat normatif-kuantitatif. Penelitian ini menunjukan bahwa status sebagai Taman Nasional belum memberikan perlindungan hukum yang kuat terhadap Taka Bonerate. Diperlukan payung hukum yang lebih konkrit untuk melindungi ekosistem terumbu karangnya.
\end{abstract}

Kata Kunci: Terumbu Karang, Taka Bonerate, Perlindungan Hukum.

\section{Abstract}

Taka Bonerate National Park is a marine park with the region's third largest atoll in the world after Kwajifein Suvadiva in the Marshall Islands and the Maldives Islands. The total area of the atoll is 220,000 hectares with coral reefs spreading up to $500 \mathrm{~km}^{2}$. There are about 295 species of reef fish and various types of high-value fish such as grouper (Epinephelus spp.), Napoleon fish (Cheilinus undulatus), and Baronang (Siganus sp). A total of 244 species of molluscs in between Lola (Trochus niloticus), Shells Goats Head (Cassis cornuta), Triton (Charonia tritonis), Batulaga (Turbo spp.). This study aims at providing legal protection for biodiversity in the National Park Takabonerate. Other research methods are normativequantitative. This study shows that the status as a national park not provide strong

1 Pengajar Hukum Lingkungan di Fakultas Hukum Universitas Hasanuddin 
legal protection against Takabonerate. Required more concrete legal basis for protecting biodiversity.

Keywords: Coral Breef, Taka Bonerate, Legal Protection.

\section{Pendahuluan}

Pasal 33 Ayat (3) UUD NRI $1945^{2}$ menegaskan negara sebagai pemegang "kuasa pengelolaan sumberdaya alam." Sebagai pemegang kuasa, negara diwajibkan oleh konstitusi untuk menggunakan kuasa tersebut sebesar-besarnya bagi kemakmuran rakyat. Paradigma negara kesejahteraan yang menjadi 'nafas' pasal tersebut semestinya dibarengi dengan tersedianya perangkat hukum (legal instrument) yang berpihak pada kepentingan rakyat secara luas.

Berpijak pada konsensus tersebut, negara dituntut untuk melaksanakan kewajibannya dalam memberikan perlindungan hukum terhadap pengelolaan dan kelestarian lingkungan hidup di darat, laut dan udara. Hal tersebut semakin dipicu oleh kegiatan yang tidak mengacu pada kriteria-kriteria pembangunan berwawasan lingkungan serta pemanfaatan sumberdaya alam laut yang berlebihan. ${ }^{3}$

Salah satu habitat ekosistem laut adalah terumbu karang. Hasil penelitian Pusat Penelitian Oseanografi Lembaga Ilmu Pengetahuan Indonesia (LIPI) mencatat, hingga 2013 pada 1.135 stasiun menunjukkan bahwa sebesar 30,4 persen kondisi terumbu karang di Indonesia mengalami kerusakan atau kurang baik. Hanya sebesar 5,29 persen dalam kondisi sangat baik, sebesar 27,14 persen masih dalam kondisi baik, dan sebesar 37,18 persen dalam kondisi cukup. ${ }^{4}$

Diperlukan upaya untuk menanggulangi hal tersebut. Salah satu bentuk upaya tersebut adalah perlindungan sumberdaya alam yang dapat dilakukan melalui konservasi dengan cara menetapkan lokasi-lokasi yang memiliki potensi keanekaragaman jenis biota laut, gejala alam dan keunikan, serta ekosistemnya menjadi Kawasan Konservasi Laut (KKL) atau disebut juga Marine Conservation Area (MCA). ${ }^{5}$

2 Pasal 33 Ayat (3) UUD 1945 “Bumi dan air dan kekayaan alam yang terkandung di dalamnya dikuasai oleh negara dan dipergunakan untuk sebesar-besar kemakmuran rakyat."

3 Strategi Utama Jejaring Kawasan Konservasi Laut; Program Rehabilitasi dan Pengelolaan Terumbu Karang Tahap II (COREMAP II), Direktorat Jenderal Kelautan, Pesisir dan Pulau-Pulau Kecil, Departemen Kelautan dan Perikanan RI, 2006, hlm 1.

4 LIPI, 30,4\% Terumbu Karang Rusak, sumber: http://kependudukan.lipi.go.id/id/berita/ liputan-media/146-lipi-30-4-persen-terumbu-karang-rusak data akses 26 Oktober 2015.

5 COREMAP II, op.cit. 
KKL merupakan wilayah perairan laut termasuk pesisir dan pulau-pulau kecil yang mencakup tumbuhan dan hewan di dalamnya, dan/atau termasuk bukti peninggalan sejarah dan sosial budaya di bawahnya, yang dilindungi secara hukum atau cara lain yang efektif baik dengan melindungi seluruh atau sebagian wilayah tersebut. Di daerah tersebut diatur zona-zona untuk mengatur kegiatan yang dapat dan tidak dapat dilakukan, misalnya pelarangan kegiatan seperti penambangan minyak dan gas bumi, perlindungan ikan, biota laut dan ekologinya untuk menjamin perlidungan yang lebih baik. ${ }^{6}$

KKL tersebut pada dasarnya merupakan gerbang terakhir perlindungan dan pemanfaatan berkelanjutan sumberdaya kelautan dan ekosistemnya. Melalui cara tersebut diharapkan upaya perlindungan secara lestari terhadap sistem penyangga kehidupan, pengawetan sumber plasma nutfah dan ekosistemnya serta pemanfaatan sumberdaya alam laut secara berkelanjutan dapat terwujud. ${ }^{7}$

TNT yang berlokasi di Kabupaten Kepulauan Selayar, Provinsi Sulawesi Selatan, merupakan salah satu Kawasan Konservasi Laut (KKL) yang dilindungi oleh negara. TNT memiliki karakteristik berupa terumbu karang tipe atol yang terbesar ketiga di dunia setelah Kwajifein di Kepulauan Marshall dan Suvadiva di Kepulauan Moldiva yaitu seluas $220.000 \mathrm{Ha}$. Secara geografis terletak di Laut Flores yaitu antara $120^{\circ} 55^{\prime}-121^{\circ} 9^{\prime}$ BT dan $6^{\circ} 41^{\prime}-7^{\circ} 70^{\prime}$ LS. $^{8}$

Sebagai suatu kawasan pelestarian alam, TNT mempunyai fungsi untuk perlindungan sistem penyangga kehidupan, pengawetan keanekaragaman jenis biota serta pemanfaatan secara lestari sumber daya alam hayati dan ekosistemnya. TNT memiliki potensi sumber daya laut berupa Terumbu Karang (231 jenis), Ikan (285 jenis), Moluska (216 jenis), Penyu (4 jenis), Echinodermata (4 jenia), Lamun (10 jenis), serta Alga (47 jenis). ${ }^{9}$ Sebagai suatu kawasan konservasi, pengelolaan sumber daya alam laut yang terkandung di dalamnya harus dilakukan secara bijaksana agar menunjang budidaya, dapat dimanfaatkan bagi kepentingan penelitian, ilmu pengetahuan, pendidikan, dan pariwisata serta peningkatan kesejahteraan masyarakat. Dengan demikian pengelolaan dan pengembangan TNT merupakan

Ibid hlm 2-3.

7 COREMAP II, ibid

8 Departemen Kehutanan RI, Taman Nasional Taka Bonerate, sumber: http://www.dephut. go.id/INFORMASI/TN\%20INDO-ENGLISH/tn_takabonerate.htm

9 Asep Sugiharta. Prospek dan Kontribusi Taman Nasional Taka Bonrate Terhadap pembangunan Daerah, (Makalah disampaikan dalam Pertemuan Regional Pengelolaan Taman Nasional Kawasan Timur Indonesia, Kelembagaan Pengelolaan Taman Nasional, Manado, 24-27 Agustus 1999). 
bagian yang tidak terpisahkan dari pembangunan daerah setempat yang diharapkan dapat memberikan kontribusi bagi pengembangan wilayah tersebut. ${ }^{10}$

Meskipun sudah ditetapkan sebagai Kawasan Konservasi, potensi ancaman kerusakan eksosistem laut di TNT tetap ada. Berdasarkan hasil survey Pusat Studi Terumbu Karang (PSTK) Unhas tahun 2000, di daerah Taka Bonerate, tingkat kerusakan rata-rata relatif lebih rendah yakni dengan penutupan karang hidup sekitar 40-60\%, dan di daerah Kepulauan Spermonde tingkat penutupan karang sekitar $25-50 \% .^{11}$

(Sulsel), masuk dalam kategori rusak parah, sedang 36 persen lainnya dalam kondisi kritis. Kerusakan yang terjadi itu tidak hanya pada kawasan terumbu karang yang secara formal dilindungi seperti TNT di Kabupaten Selayar, tetapi juga hampir menyeluruh di pesisir Sulsel mulai dari sebelah Selatan hingga ke Teluk Bone di pantai Timur Sulsel. ${ }^{12}$

Ekspedisi Takabonerate tahun 2009 lalu menyimpulkan bahwa terumbu karang di sejumlah titik penyelaman TNT, Sulawesi Selatan, umumnya telah mati akibat penggunaan bom ikan. Pendataan Balai TNT pada tahun 2009 juga memperkirakan, luasan kondisi dan luasan terumbu karang lima tahun terakhir ini berkurang. Survei tahun 2004 menunjukkan, tutupan terumbu karang di TNT masih sekitar 78 persen. Namun, hasil sementara survei tahun 2009 menunjukkan, tutupan terumbu karang di kawasan itu tinggal 60-70 persen. ${ }^{13}$

Dari kasus-kasus yang terekam, penyebab kerusakan terumbu karang diantaranya adalah pembangunan di kawasan pesisir, pembuangan limbah dari berbagai aktivitas di darat maupun di laut, sedimentasi akibat rusaknya wilayah hulu dan daerah aliran sungai, pertambangan, penangkapan ikan merusak yang menggunakan sianida dan alat tangkap terlarang, pemutihan karang akibat perubahan iklim, serta penambangan terumbu karang.

Menurut penulis, kerusakan ekosistem laut di TNT setidaknya bisa diidentifikasi dari beberapa kasus. Pertama, penggunaan bom ikan oleh masyarakat di sekitar

10 Ibid.

11 Sudirman, "Warning Atas Kerusakan Hutan Bawah Laut", Fakultas Ilmu Kelautan dan Perikanan Unhas (tanpa tahun), hlm 1.

12 Coremap.or.id., 40\% Terumbu Karang Sulsel Rusak Parah, sumber: http://regional. coremap.or.id/print/article.php?id=542 diakses dari http://www.kompas.com/ver1/ Iptek/0709/10/174020.htm, data diakses pada hari Minggu 18/10/2015 pukul 14.00 WITA.

13 Kompas, Sebagian Terumbu Karang Taka Bonerate Telah Mati, sumber:http://bisniskeuangan. kompas.com/read/2009/10/27/07414877/Sebagian.Terumbu.Karang.Takabonerate.Telah. Mati data diakses pada hari Minggu 18/10/2015 pukul 14.00 wita. 
perairan atau nelayan pendatang. Selain karena kurangnya pemahaman terhadap peraturan perundang-undangan, kondisi ini juga terjadi akibat ketidakpahaman masyarakat terhadap pentingnya menjaga kelestarian ekosistem perairan, khususnya terumbu karang. Kedua, perburuan biota laut secara besar-besaran, khususnya biota laut yang dilindungi. Ketiga, tingkat laju kerusakan ekosistem laut tidak sebanding dengan upaya pemulihan melalui konservasi. Keempat, lemahnya perangkat kelembagaan pemerintah daerah untuk melindungi ekosistem taman laut, termasuk dalam hal ini TNT.

Kondisi demikian menunjukkan bahwa kerusakan ekosistem bawah laut di TNT nyata terjadi. Sehingga diperlukan penguatan terhadap intrumen hukum yang sudah ada, guna memperkuat perlindungan hukumnya. Penguatan ini dapat dilakukan dengan dua cara. Pertama, memperbaiki regulasi di tingkat nasional. Kedua, membentuk perangkat peraturan perundang-undangan di tingkat lokal yang diselaraskan dengan peraturan perundang-undangan di tingkat nasional yang menjadi payung hukumnya (umbrella act). Hal ini penting dilakukan untuk menyesuaikan regulasi di tingkat nasional dengan kebutuhan di daerah pasca berlakunya UU Pemerintahan Daerah terbaru (UU No. 23 Tahun 2014). ${ }^{14}$

Penguatan perlindungan hukum terhadap wilayah perairan menjadi penting mengingat wilayah laut dan perairan di sekitarnya saat ini menjadi perhatian dunia. Konflik di Laut China Selatan antara 6 (enam) negara: China, Taiwan, Malaysia, Filipina, Indonesia, dan Brunei, ${ }^{15}$ menyadarkan dunia jika laut, menyimpan potensi sumberdaya alam yang sangat besar dan strategis. Buku "Konflik Laut China Selatan dan Implikasinya Terhadap Kawasan"16 mengurai secara komprehensif silang kepentingan enam negara perairan terhadap Laut China Selatan. Atas fakta itu, Indonesia sebagai negara kepulauan terbesar sepatutnya sadar dan segera memperkuat instrumen hukum untuk melindungi kepentingan nasionalnya di wilayah laut dan perairan di sekitarnya.

Beberapa perangkat undang-undang yang telah ada masih mampu menjawab kebutuhan jangka pendek, akan tetapi dipandang belum memenuhi kebutuhan jangka panjang. Oleh karenanya, penguatan serta penyelarasan instrumen hukum peraturan perundang-undang; baik nasional maupun lokal, terkait isu ekosistem

14 Indonesia, Undang-Undang tentang Pemerintahan Daerah, UU No. 23 Tahun 2014, LN No. 244 Tahun 2014, TLN No. 5587.

15 Empat negara terakhir adalah anggota ASEAN.

16 "Konflik Laut China Selatan dan Implikasinya Terhadap Kawasan, Diterbitkan oleh P3DI Setjen DPR Republik Indonesia dan Azza Grafika, 2013. 
laut dan perairan mutlak diperlukan untuk menjawab tantangan kebutuhan jangka panjang.

\section{Pembahasan}

\subsection{Perlindungan Hukum TNT: Pendekatan Undang-Undang}

Tulisan ini bersandar pada teori besar tentang perlindungan hukum (legal protection), dengan meletakkan prinsip kewajiban Negara (state obligation) untuk melaksanakan perlindungan hukum itu. Pertama, tak ada janji tanpa kewajiban. Seluruh deklarasi dan perjanjian internasional selalu mengandung prinsip kewajiban negara. Kedua, dasar kewajiban negara diletakan karena subyek hukum dalam perjanjian internasional adalah negara, sama sekali bukan individu atau badan lainnya. Kewajiban ini tidaklah diajukan kepada perorangan, karena setiap orang bukanlah subyek hukum dalam perjanjian yang dimaksud. Ketiga, tak ada kewajiban tanpa tanggungjawab. Peletakan prinsip state obligation tentu saja bertalian pula dengan tanggungjawab negara (state responsibility). Konsistensi dari seluruh rangkaian disepakatinya perjanjian dan pelaksanaan kewajiban selalu menuntut tanggungjawab sebagai pasangan yang logisnya. Jika negara gagal atau lalai menunaikan janji dan kewajibannya, maka kepada negara pulalah dituntut tanggungjawabnya. Keempat, sebagai pihak yang berjanji, negara bukan saja selalu berpotensi, tetapi secara faktual mengingkari atau melanggar janjinya sendiri. Atas pengingkaran atau pelanggaran ini pula, negara-negara dituntut tanggungjawabnya. ${ }^{17}$

Menurut Fitzgerald, yang menjelaskan teori perlindungan hukum Salmond, bahwa hukum bertujuan mengintegrasikan dam mengkoordinasikan berbagai kepentingan dalam masyarakat karena dalam suatu lalu-lintas kepentingan, perlindungan terhadap kepentingan tertentu dapat dilakukan dengan cara membatai berbagai kepentingan di lain pihak. ${ }^{18}$ Kepentingan hukum adalah mengurusi hak dan kepentingan manusia, sehingga hukum memiliki otoritas tertinggi untuk menentukan kepentingan manusia yang perlu diatur dan dilindungi. ${ }^{19}$ Perlindungan hukum harus melihat tahapan yakni perlindungan hukum lahir dari suatu ketentuan hukum dan segala peraturan hukum yang diberikan oleh masyarakat yang pada

17 Menggugat Negara:Rasionalitas Demokrasi,HAMdanKebebasan.(Jakarta:PBHIdanEuropean Union (UE), 2005).

18 Satijipto Raharjo, Ilmu Hukum (Bandung : PT. Citra Aditya Bakti, 2000) hlm 53.

19 Ibid hlm 69. 
dasarnya merupakan kesepakatan masyarakat tersebut untuk mengatur hubungan prilaku antara angota-anggota masyarakat dan antara perseorangan dengan pemerintah yang dianggap mewakili kepentingan masyarakat.

Salah satu bentuk perlindungan hukum dalam tanggungjawab negara terhadap pengelolaan dan pelestarian lingkungan hidup adalah dengan membentuk peraturan perundang-undangan. Di bawah ini akan disebutkan sejumlah peraturan perundang-undangan yang menjadi payung hukum perlindungan dan pelestarian lingkungan hidup dan ekosistem hayati dan ekosistem laut, termasuk di TNT. Dalam uraian ini, Penulis juga mengidentifikasi persoalan di dalamnya.

\section{1) UU No 5 Tahun 1990 Tentang Konservasi Keanekaragaman Hayati dan} Ekosistemnya ${ }^{20}$

Selain mengacu pada UU No 4 Tahun 1982 tentang Ketentuan-ketentuan Pokok Pengelolaan Lingkungan Hidup, pengelolaan TNT mengacu pada UU No 5 Tahun 1990 tentang konservasi sumberdaya alam hayati dan ekosistemnya. Ada 2 (dua) kata penting dalam undang-undang ini yaitu "konservasi" dan "ekosistem" sumberdaya alam hayati. Pasal 1 ayat (2) undang-undang ini, menyatakan jika "konservasi sumber daya alam hayati adalah pengelolaan sumber daya alam hayati yang pemanfaatannya dilakukan secara bijaksana untuk menjamin kesinambungan persediaannya dengan tetap memelihara dan meningkatkan kualitas keanekaragaman dan nilainya." Kemudian Pasal 1 ayat (3) "ekosistem sumber daya alam hayati adalah sistem hubungan timbal balik antara unsur dalam alam, baik hayati maupun non hayati yang saling tergantung dan berpengaruh mempengaruhi."

Lahirnya undang-undang ini sebagai bentuk kesadaran Negara akan pentingnya melestarikan kekayaan sumberdaya alam hayati. Konsideran UU No 5 Tahun 1990, bahwa "sumber daya lama hayati Indonesia dan ekosistemnya yang mempunyai kedudukan serta peranan penting bagi kehidupan adalah karunia Tuhan Yang Maha Esa, oleh karena itu perlu dikelola dan dimanfaatkan secara lestari, selaras, serasi dan seimbang bagi kesejahteraan masyarakat Indonesia pada khususnya dan umat manusia pada umumnya, baik masa kini maupun masa depan." Bahkan dari pemberlakuan UU No 5 Tahun 1990 ini, Indonesia dipandang satu langkah lebih maju dari dunia internasional yang baru menganggap penting untuk melindungi keanekaragaman hayati dan ekosistem pendukungnya melalui

20 Indonesia, Undang-Undang tentang Konservasi Sumber Daya Alam Hayati dan Ekosistemnya, UU No. 5 Tahun 1990, LN Tahun 1990 No. 49. 
United Nations Convention on Biological Diversity (Konvensi Perserikatan BangsaBangsa Mengenai Keanekaragaman Hayati) empat tahun kemudian.

Undang-undang ini juga mengatur keberadaan Taman Nasional, seperti diatur dalam Pasal 29 ayat (1) "Kawasan pelestarian alam sebagaimana dimaksud dalam Pasal 1 angka 13 terdiri dari: (a) taman nasional; (b) taman hutan raya; (c) taman wisata alam." Keberadaan TNT cukup mendapat perlindungan dalam undang-undang ini. Meski tidak secara spesifik mengatur perlindungan terhadap ekosistem laut dan perairan disekitarnya, termasuk ekosistem terumbu karang. Mestinya, “konservasi” sebagaimana disebut dalam Pasal 1 diatas dijabarkan secara rinci; konservasi sumberdaya alam di darat dan konservasi sumberdaya alam di laut, guna mendorong lahirnya peraturan pelaksana bagi penguatannya.

\section{2) UU No 5 Tahun 1994 tentang Pengesahan United Nations Convention On} Biological Diversity (Konvensi PBB Mengenai Keanekaragaman Hayati) ${ }^{21}$

Empat tahun kemudian setelah berlakunya UU No 5 Tahun 1990, pemerintah Indonesia meratifikasi United Nations Convention on Biological Diversity $^{22}$ (Konvensi Perserikatan Bangsa-Bangsa Mengenai Keanekaragaman Hayati) melalui Undang-undang Nomor 5 Tahun 1994. Pertimbangan pengesahan Konvensi ini antara lain adalah, bahwa keanekaragaman hayati di dunia, khususnya di Indonesia, berperan penting untuk kelanjutan proses evolusi serta terpeliharanya keseimbangan ekosistem dan sistem kehidupan biosfer. Di samping itu, keanekaragaman hayati yang meliputi ekosistem, jenis dan genetik yang mencakup hewan, tumbuhan, dan jasad renik (microorganism), perlu dijamin keberadaan dan keberlanjutannya bagi kehidupan.

Pengesahan United Nations Conventions on Biological Diversity ini tidak bisa dilepaskan dari Undang-undang Nomor 17 Tahun 1985 tentang Ratifikasi United Nations Convention on the Law of the Sea (UNCLOS) 1982. Konvensi ini mempunyai kekuatan berlaku tanggal 16 November 1994. Sebagai perangkat hukum pendukung berlaku UU Nomor 6 Tahun 1996 tentang Perairan Indonesia dan PP Nomor 19 Tahun 1997 tentang Pengendalian Pencemaran dan

21 Indonesia, Undang-Undang tentang Pengesahan United Nations Convention on Biological Diversity (Konvensi Perserikatan Bangsa-Bangsa Mengenai Keanekaragaman Hayati), UU No. 5 Tahun 1994.

22 United Nations, Convention on Biological Diversity, Rio de Jeneiro, 5 June 1992. Dapat dibuka di:https://treaties.un.org/pages/ViewDetails.aspx?src=TREATY\&mtdsg_no=XXVII$\underline{8 \text { \&chapter }=27 \& \text { lang }=\text { en }}$. 
atau Perusakan Laut. ${ }^{23}$

Dalam hukum internasional, dikenal asas pacta sun servanda, yang mengikat secara hukum dan memberikan kewajiban bagi negara-negara untuk mematuhi dan mengimplementasikan dalam hukum nasional. Atas dasar itulah, sebagai negara kepulauan yang sangat berkepentingan dalam upaya perlindungan laut dan perairan disekitarnya, Indonesia wajib mematuhi dan melaksanakan prinsip-prinsip yang terkandung dalam konvensi internasional tersebut. Dalam konteks itu, keberadaan UU Nomor 6 Tahun 1996 tentang Perairan Indonesia dan PP Nomor 19 Tahun 1997 tentang Pengendalian Pencemaran dan atau Perusakan Laut, penulis pandang sudah menjadi sikap Indonesia terhadap konvensi tersebut.

\section{3) UU No 27 Tahun 2007 tentang Pengelolaan Wilayah Pesisir dan Pulau-Pulau Kecil (UU WP3K) ${ }^{24}$}

UU No 27 Tahun 2007 tentang Pengelolaan Wilayah Pesisir dan PulauPulau Kecil (UU WP3K) menjadi tonggak baru dalam pengelolaan, pelestarian dan perlindungan wilayah pesisir laut. Dalam bagian pertimbangan undangundang ini, negara memandang bahwa "wilayah Pesisir dan Pulau-Pulau Kecil memiliki keragaman potensi Sumber Daya Alam yang tinggi, dan sangat penting bagi pengembangan sosial, ekonomi, budaya, lingkungan, dan penyangga kedaulatan bangsa, oleh karena itu perlu dikelola secara berkelanjutan dan berwawasaan global, dengan memperhatikan aspirasi dan partisipasi masyarakat, dan tata nilai bangsa yang berdasarkan norma hukum nasional."

Perlindungan hukum terhadap wilayah pesisir dan pulau-pulau kecil berpijak pada asas "kepastian hukum" sebagaimana termuat dalam Pasal 3 undang-undang ini. Selain itu, konservasi wilayah pesisir juga diatur dalam undang-undang ini. Pasal 1 ayat (19) menyebutkan "Konservasi Wilayah Pesisir dan Pulau-Pulau Kecil adalah upaya perlindungan, pelestarian, dan pemanfaatan Wilayah Pesisir dan Pulau-Pulau Kecil serta ekosistemnya untuk menjamin keberadaan, ketersediaan, dan kesinambungan Sumber Daya Pesisir dan Pulau-Pulau Kecil." Kemudian ayat selanjutnya (ayat 20) menyebutkan "kawasan konservasi di Wilayah Pesisir dan Pulau-Pulau Kecil adalah kawasan pesisir dan pulau-pulau kecil dengan ciri khas tertentu yang dilindungi untuk mewujudkan pengelolaan Wilayah

23 Ibid hlm 356.

24 Indonesia, Undang-Undang tentang Pengelolaan Wilayah Pesisir dan Pulau-Pulau Kecil, UU No 27 Tahun 2007, LN No. 84 Tahun 2007, TLN No. 4793. 
Pesisir dan Pulau-Pulau Kecil secara berkelanjutan. dengan tetap memelihara dan meningkatkan kualitas nilai dan keanekaragamannya."

Dalam advokasi lingkungan hidup yang lebih luas, lahirnya UU WP3K ini menambah kuat upaya perlindungan terhadap pengelolaan wilayah pesisir dan pulau-pulau kecil, termasuk kawasan TNT yang secara geografis berada di wilayah kepulauan Selayar. Hadirnya undang-undang ini bertujuan untuk: pertama, melindungi, mengonservasi, merehabilitasi, memanfaatkan, dan memperkaya Sumber Daya Pesisir dan Pulau-Pulau Kecil serta sistem ekologisnya secara berkelanjutan. Kedua, menciptakan keharmonisan dan sinergi antara Pemerintah dan Pemerintah Daerah dalam pengelolaan Sumber Daya Pesisir dan Pulau-Pulau Kecil. Ketiga, memperkuat peran serta masyarakat dan lembaga pemerintah serta mendorong inisiatif masyarakat dalam pengelolaan Sumber Daya Pesisir dan Pulau-Pulau Kecil agar tercapai keadilan, keseimbangan, dan keberkelanjutan. Keempat, meningkatkan nilai sosial, ekonomi, dan budaya Masyarakat melalui peran serta masyarakat dalam pemanfaatan Sumber Daya Pesisir dan Pulau-Pulau Kecil. ${ }^{25}$

Konservasi wilayah pesisir dan pulau-pulau kecil juga menjadi isu utama dalam undang-undang ini. Tujuan Konservasi Wilayah Pesisir dan Pulau-Pulau Kecil: pertama, menjaga kelestarian Ekosistem Pesisir dan Pulau-Pulau Kecil. Kedua, melindungi alur migrasi ikan dan biota laut lain. Ketiga, melindungi habitat biota laut. Keempat, melindungi situs budaya tradisional.

Meski demikian, undang-undang ini bukannya tanpa cacat. Meski menjadi payung hukum dalam pengelolaan wilayah pesisir dan pulau-pulau kecil, termasuk ekosistem hayati di dalamnya, undang-undang ini meyimpan masalah terkait Hak Penguasaan Perairan Pesisir (HP3). ${ }^{26}$ Gugatan uji materi terhadap UU WP3K yang diajukan oleh Koalisi Tolak Hak Pengusahaan Perairan Pesisir di yang dikabulkan Mahkamah Konstitusi (MK) ${ }^{27}$ pada 2011 lalu menegaskan masalah ini. Menurut MK, pemberian HP3 oleh pemerintah kepada pihak swasta adalah bertentangan dengan UUD 1945 khususnya Pasal 33 Ayat (4) UUD 1945 yang menyatakan "perekonomian nasional diselenggarakan berdasar atas demokrasi ekonomi dengan prinsp kebersamaan, efisiensi

25 Pasal 4 UU WP3K

26 Pengertian HP3 dalam UU ini adalah hak atas bagian-bagian tertentu dari perairan pesisir untuk usaha kelautan dan perikanan, serta usaha lain yang terkait dengan pemanfaatan Sumber Daya Pesisir dan Pulau-Pulau Kecil yang mencakup atas permukaan laut dan kolom air sampai dengan permukaan dasar laut pada batas keluasan tertentu.

Putusan Mahkamah Konstitusi Nomor 3/PUU-VIII/2010. 
berkeadilan, berkelanjutan, berwawasan lingkungan, kemandirian, serta dengan menjaga keseimbangan kemajuan dan kesatuan ekonomi nasional." MK menyatakan, pemberian HP3 melanggar prinsip demokrasi ekonomi karena akan mengakibatkan wilayah perairan pesisir dan pulau-pulau kecil menjadi wilayah HP3 yang dikuasai oleh pemilik modal besar. Sebaliknya bagi masyarakat nelayan tradisional yang sebagian besar berdiam di wilayah pesisir dan pulau-pulau kecil dan menggantungkan hidup dan kehidupannya pada sumber daya pesisir akan tersingkir. Sehingga dalam kondisi yang demikian, negara telah lalai menyelenggarakan tanggung jawabnya untuk melaksanakan perekonomian nasional yang memberikan perlindungan dan keadilan rakyat.

4) UU No 1 Tahun 2014 tentang Perubahan Atas Undang-Undang Nomor 27 Tahun 2007 Tentang Pengelolaan Wilayah Pesisir dan Pulau-Pulau Kecil ${ }^{28}$

UU No 1 Tahun 2014 merupakan perubahan atas UU No 27 Tahun 2007 tentang Pengelolaan Wilayah Pesisir dan Pulau-Pulau Kecil. Rentang waktu 7 (tujuh) tahun membuat pemerintah semakin sadar untuk memperkuat perlindungan hukum terhadap wilayah pesisir dan pulau-pulau kecil. Kesadaran itu tampak pada beberapa pasal dalam UU No 1 Tahun 2014 yang mengalami perubahan jika dibandingkan dengan UU No 27 Tahun 2007. Beberapa perubahan tersebut diantaranya:

28 Indonesia, Undang-undang tentang Perubahan Atas Undang-Undang Nomor 27 Tahun 2007 Tentang Pengelolaan Wilayah Pesisir dan Pulau-Pulau Kecil, UU No. 1 Tahun 2014, LN No. 2 Tahun 2014, TLN No. 5490. 
Tabel: Perbandingan Beberapa Pasal dalam UU No. 27 Tahun 2007 dan UU No. 1 Tahun 2014.

\begin{tabular}{|c|c|c|}
\hline UU No 27 Tahun 2007 & UU No 1 Tahun 2014 & Keterangan \\
\hline $\begin{array}{l}\text { Pasal } 1 \text { angka (1): } \\
\text { "Pengelolaan Wilayah } \\
\text { Pesisir dan Pulau-Pulau } \\
\text { Kecil adalah suatu } \\
\text { proses perencanaan, } \\
\text { pemanfaatan, } \\
\text { pengawasan, dan } \\
\text { pengendalian Sumber } \\
\text { Daya Pesisir dan Pulau- } \\
\text { Pulau Kecil antarsektor, } \\
\text { antara Pemerintah dan } \\
\text { Pemerintah Daerah, } \\
\text { antara ekosistem darat } \\
\text { dan laut, serta antara } \\
\text { ilmu pengetahuan } \\
\text { dan manajemen } \\
\text { untuk meningkatkan } \\
\text { kesejahteraan masyarakat. }\end{array}$ & $\begin{array}{l}\text { "Pengelolaan Wilayah } \\
\text { Pesisir dan Pulau- } \\
\text { Pulau Kecil adalah } \\
\text { suatu pengoordinasian } \\
\text { perencanaan, pemanfaatan, } \\
\text { pengawasan, dan } \\
\text { pengendalian sumber daya } \\
\text { pesisir dan pulau-pulau } \\
\text { kecil yang dilakukan } \\
\text { oleh Pemerintah dan } \\
\text { Pemerintah Daerah, } \\
\text { antarsektor, antara } \\
\text { ekosistem darat dan } \\
\text { laut, serta antara ilmu } \\
\text { pengetahuan dan } \\
\text { manajemen untuk } \\
\text { meningkatkan kesejahteraan } \\
\text { rakyat." }\end{array}$ & $\begin{array}{l}\text { UU No } 1 / 2014 \\
\text { lebih jelas } \\
\text { memuat peran } \\
\text { pemerintah dan } \\
\text { pemerintah } \\
\text { daerah dalam } \\
\text { pengelolaan } \\
\text { WPPK. }\end{array}$ \\
\hline $\begin{array}{l}\text { Pasal } 1 \text { angka (17) } \\
\text { "Rencana Zonasi Rinci } \\
\text { adalah rencana detail } \\
\text { dalam } 1 \text { (satu) Zona } \\
\text { berdasarkan arahan } \\
\text { pengelolaan didalam } \\
\text { Rencana Zonasi dengan } \\
\text { memperhatikan daya } \\
\text { dukung lingkungan dan } \\
\text { teknologi yang diterapkan } \\
\text { serta ketersediaan sarana } \\
\text { yang pada gilirannya } \\
\text { menunjukkan jenis dan } \\
\text { jumlah surat izin yang } \\
\text { dapat diterbitkan oleh } \\
\text { Pemerintah Daerah." }\end{array}$ & $\begin{array}{l}\text { "Rencana Zonasi Rinci } \\
\text { adalah rencana detail dalam } \\
1 \text { (satu) Zona berdasarkan } \\
\text { arahan pengelolaan di } \\
\text { dalam Rencana Zonasi yang } \\
\text { dapat disusun oleh } \\
\text { Pemerintah Daerah dengan } \\
\text { memperhatikan daya dukung } \\
\text { lingkungan dan teknologi } \\
\text { yang dapat diterapkan } \\
\text { serta ketersediaan sarana } \\
\text { yang pada gilirannya } \\
\text { menunjukkan jenis dan } \\
\text { jumlah surat izin yang } \\
\text { diterbitkan oleh Pemerintah } \\
\text { dan Pemerintah Daerah. }\end{array}$ & $\begin{array}{l}\text { UU No 1/2014 } \\
\text { lebih tegas } \\
\text { mengatur } \\
\text { keterlibatan } \\
\text { pemerintah pusat } \\
\text { dalam pembuatan } \\
\text { Rencana Zonasi. }\end{array}$ \\
\hline
\end{tabular}

Selain itu, HP-3 dalam UU No 27 Tahun 2007 yang telah dibatalkan oleh MK, oleh UU No 1 Tahun 2014 berganti menjadi izin lokasi. Termuat dalam Pasal 16: 
(1) Setiap Orang yang melakukan pemanfaatan ruang dari sebagian Perairan Pesisir dan pemanfaatan sebagian pulau-pulau kecil secara menetap wajib memiliki Izin Lokasi.

(2) Izin Lokasi sebagaimana dimaksud pada ayat (1) menjadi dasar pemberian Izin Pengelolaan."

Membandingkan kedua undang-undang ini, jika HP3 dalam UU No 27 Tahun 2007 memberikan "hak menguasai" kepada perorangan, badan usaha, dan masyarakat adat, maka "izin lokasi" dalam UU No 1 Tahun 2014 hanya memberikan "hak pengelolaan", penguasaan terhadap tanah tetap dimiliki oleh negara.

Jika dilacak, izin lokasi dalam undang-undang ini merujuk pada Izin Lingkungan ${ }^{29}$ sebagaimana termuat dalam UU No 32 Tahun 2009 tentang Perlindungan dan Pengelolaan Lingkungan Hidup, serta Peraturan Presiden No 122 Tahun 2012 tentang Reklamasi di Wilayah Pesisir dan Pulau-Pulau Kecil. Beberapa perubahan Pasal dalam UU No 1 Tahun 2014 menandakan jika pemerintah pusat terlibat lebih aktif, salah satunya dalam penerapan rencana zonasi, agar tidak terjadi manipulasi perizinan zonasi yang berpotensi menimbulkan akibat hukum negatif.

Namun meskipun dipandang sebagai langkah maju dalam perlindungan terhadap kedaulatan negara atas wilayah pesisir dan pulau-pulau kecil, izin lokasi sebagai syarat melakukan "reklamasi" dalam UU dan PP ini menyimpan bahaya laten. Bahaya laten yang dimaksud adalah potensi kerusakan lingkungan pesisir dan pulau-pulau kecil akibat kegiatan reklamasi yang dilakukan oleh perorangan atau badan usaha. Kasus penolakan reklamasi di Teluk Buloa (Bali) ${ }^{30}$ dan reklamasi di pesisir Makassar (Sulsel) ${ }^{31}$ yang kencang dikampanyekan aktivis lingkungan memberikan pesan penting akan ancaman

29 Izin lingkungan adalah izin yang diberikan kepada setiap orang yang melakukan usaha dan/ atau kegiatan yang wajib amdal atau UKL-UPL dalam rangka perlindungan dan pengelolaan lingkungan hidup sebagai prasyarat untuk memperoleh izin usaha dan/atau kegiatan.

30 Republika, WALHI Tolak Pengerukan Pasir untuk Teluk Benoa, sumber: http://nasional. republika.co.id/berita/nasional/daerah/15/03/26/nlgihj-walhi-tolak-pengerukan-pasiruntuk-teluk-benoa. Lihat juga: Republika, Gubernur Jatim Didesak Tolak Izin Pengerukan Pasir Pesisir Banyuwangi, sumber: http://www.republika.co.id/berita/nasional// umum/15/04/08/nmhwrp-gubernur-jatim-didesak-tolak-izin-pengerukan-pasir-pesisirbanyuwangi, data akses pada Kamis 26 Nov 2015 pukul 15.30 wita.

31 Kompas, Aktivis Tolak Rencana Reklamasi 4.000 Ha, http://print.kompas.com/ baca/2015/08/21/Aktivis-Tolak-Rencana-Reklamasi-4-000-Hektar data akses pada Kamis 26 Nov 2015 pukul 15.30 wita. 
nyata terhadap kerusakan lingkungan pesisir dan pulau-pulau kecil akibat kegiatan reklamasi yang tidak mematuhi persyaratan perundang-undangan.

\section{5) UU No 45 Tahun 2009 Tentang Perikanan ${ }^{32}$}

Undang-undang ini merupakan perubahan atas UU No 31 Tahun 2004 tentang Perikanan. Keberadaan UU ini cukup penting dalam melindungi habitat ikan di TNT. Sebagaimana disinggung sebelumnya, jika di TNT terdapat sekitar 295 jenis ikan karang dan berbagai jenis ikan bernilai ekonomis tinggi seperti Kerapu (Epinephelus spp.), Baronang (Siganus sp), dan Ikan Naopoleon (Cheilinus undulatus) sebagai jenis ikan yang dilindungi.

Lahirnya UU ini atas kesadaranjika UU No31 Tahun 2004 tentang Perikanan “.....belum sepenuhnya mampu mengantisipasi perkembangan teknologi dan kebutuhan hukum dalam rangka pengelolaan dan pemanfaatan potensi sumberdaya ikan." 33 Salah satu bentuk kegiatan dalam upaya perlindungan, pelestarian dan pemanfaatam sumberdaya ikan di TNT adalah melalui kegiatan Konservasi Sumber Daya Ikan. Konservasi Sumber Daya Ikan adalah upaya perlindungan, pelestarian, dan pemanfaatan sumber daya ikan, termasuk ekosistem, jenis, dan genetik untuk menjamin keberadaan, ketersediaan, dan kesinambungannya dengan tetap memelihara dan meningkatkan kualitas nilai dan keanekaragaman sumber daya ikan. ${ }^{34}$

Melalui UU ini, perlindungan hukum terhadap kelestarian ikan di TNT sangat penting jika dikaji dari sudut pandang ekonomi dan kedaulatan negara. Faktanya, penggunaan bom ikan oleh nelayan, termasuk nelayan pendatang dan nelayan asing yang melakukan aktivitas tangkap ikan di perairan Indonesia di sekitar kepulauan Selayar hingga ke TNT, mengancam ekosistem terumbu karang sekaligus mengancam populasi ikan. ${ }^{35}$ Hal ini tetap terjadi meskipun ancaman sanksi pidana sudah tertera dalam undang-undang ini. Selain Ikan Napoleon, anak ikan hiu (Superordo selachimorpha) yang ada di perairan sekitar TNT juga terancam punah. Data dari Koordinator Konservasi WWF-Indonesia menjelaskan, terhitung sejak 14 September 2014, sebanyak lima spesies hewan predator yang berada di perairan Indonesia sudah terancam punah

32 Indonesia, Undang-Undang tentang Perubahan atas Undang-Undang No. 31 Tahun 2004 tentang Perikanan, UU No. 45 Tahun 2009, LN No. 154 Tahun 2009, TLN No. 5073.

33 Konsideran huruf (c) UU No 45 tahun 2009 tentang Perikanan.

34 Pasal 1 angka (8) UU No 45 Tahun 2009 tentang Perikanan.

35 http://www.mongabay.co.id/tag/bom-ikan/ data akses pada hari Kamis 26 November 2015 pukul 15.45 wita. 
sehingga mendapatkan perlindungan lebih serius dari Konvensi Perdagangan Internasional terhadap Satwa dan Tumbuhan yang Terancam Punah (Convention on International Trade in Endangered Species of Wild Flora and Fauna/CITES). ${ }^{36}$

\section{6) UU No 32 Tahun 2009 Tentang Perlindungan dan Pengelolaan Lingkungan Hidup (UU PPLH) ${ }^{37}$}

UU No 32 Tahun 2009 tentang Perlindungan dan Pengelolaan Lingkungan Hidup (UUPPLH) adalah undang-undang terlengkap dalam bidang lingkungan hidup yang memuat ketentuan tentang lingkungan hidup. Terdiri dari 127 Pasal dan 17 Bab, lebih lengkap dibandingkan dua undang-undang di bidang lingkungan hidup sebelumnya (UULH No 4 Tahun 1982 dan UUPLH No 23 Tahun 1997). Berlakunya UUPPLH No 32 Tahun 2009 ini juga menyatakan bahwa UU No 23 Tahun 1997 tidak berlaku lagi. ${ }^{38}$

UUPPLH ini juga memuat lebih lengkap asas-asas yang berkaitan dengan lingkungan hidup. Seperti disebutkan dalam Pasal 2, bahwa perlindungan dan pengelolaan lingkungan hidup dilaksanakan berdasarkan asas: tanggung jawab negara, kelestarian dan keberlanjutan, keterpaduan, manfaat, kehatihatian, keadilan, ekoregion, keanekaragaman hayati, pencemar membayar, partisipatif, kearifan lokal, dan tata kelola pemerintahan yang baik.

Penambahan asas dalam UU PPLH ini memperluas sejumlah asas yang tercantum dalam UU No 23 Tahun 1997 yang hanya mencantumkan 3 (tiga) asas; asas tanggung jawab negara, asas berkelanjutan, dan asas manfaat. Penulis memandang pencantuman asas keanekaragaman hayati dan asas pencemar membayar merupakan langkah maju dalam melindungi lingkungan hidup, khususnya terkait dengan keanekaragaman hayati dalam wilayah pesisir dan pulau-pulau kecil, seperti ekosistem hayati di TNT.

\section{7) UU No 23 Tahun 2014 tentang Pemerintahan Daerah ${ }^{39}$}

Peran pemerintah daerah dalam pengelolaan dan pelestarian wilayah laut, pesisir dan pulau-pulau kecil telah diatur dalam Pasal 1 UU WP3K.

36 PKSPL-IPB, Sang Predator Terancam Punah, sumber: http://pkspl.ipb.ac.id/berita-sangpredator-terancam-punah.html\#ixzz3vYTyhyON data akses pada hari Kamis 26 November pukul 16.05 wita.

37 Indonesia, Undang-Undang tentang Perlindungan dan Pengelolaan Lingkungan Hidup, UU No. 32 Tahun 2009, LN No. 140 Tahun 2009, TLN No. 5059.

38 Termuat dalam Pasal 125 UUPLH, Ibid.

39 UU No. 23 Tahun 2014, Op. Cit. 
Dalam UU No 23 Tahun 2014 tentang Pemerintahan Daerah (UU Pemda), sektor kelautan dan perikanan juga menjadi urusan pemerintah daerah. Pasal 12 ayat (3) UU Pemda menyebutkan bahwa "Urusan Pemerintahan Pilihan sebagaimana dimaksud dalam Pasal 11 ayat (1) meliputi: a. kelautan dan perikanan; [...]" Sebagaimana UU WP3K yang mengatur peran pemerintah pusat dan daerah, UU Pemda juga membagi kewenangan pemerintah pusat dan daerah dalam pengelolaan wilayah laut. Pasal 14 ayat (1) UU Pemda menyebutkan bahwa "Penyelenggaraan Urusan Pemerintahan bidang kehutanan, kelautan, serta energi dan sumber daya mineral dibagi antara Pemerintah Pusat dan Daerah provinsi."

UU Pemda tidak mengatur secara spesifik konsep pengelolaan wilayah laut. Isu kelautan dalam UU Pemda hanya menyangkut hal-hal bersifat umum seperti; teritorial, bagi hasil kelautan antara Pusat dan Daerah, serta hal-hal umum lainnya. Hal ini dimaklumi mengingat isu kelautan, pesisir dan pulaupulau kecil sudah diatur dalam undang-undang tersendiri; UU WP3K dan UU Perairan Indonesia. Dalam wujud yang lebih konkrit, pemerintah daerah bisa membuat Peraturan Daerah (Perda) atas isu sektoral sesuai kebutuhan daerah, termasuk didalamnya adalah Perda bidang kelautan, pesisir dan pulau-pulau kecil, bagi daerah yang sebagian besar luas wilayahnya adalah laut, misanya Kabupaten Kepulauan Selayar di Propinsi Sulawesi Selatan yang menjadi lokasi TNT.40

\subsection{Peran Pemerintah Daerah}

Pemerintah Daerah, dalam hal ini Pemerintah Daerah Kabupaten Kepulauan Selayar juga dituntut berperan dalam menjaga kelangsungan dan pelestarian ekosistem hayati di wilayah pesisir dan pulau-pulau kecil. Sebagaimana diamanatkan dalam Pasal 1 UU WP3K No 1 Tahun 2014, bahwa 'Pengelolaan Wilayah Pesisir dan Pulau-Pulau Kecil adalah suatu pengoordinasian perencanaan, pemanfaatan, pengawasan, dan pengendalian sumber daya pesisir dan pulau-pulau kecil yang dilakukan oleh Pemerintah dan Pemerintah Daerah, antarsektor, antara ekosistem darat dan laut, serta antara ilmu pengetahuan dan manajemen untuk meningkatkan kesejahteraan rakyat."

Demikian pula dalam Pasal 12 UU No 23 Tahun 2014 tentang Pemerintahan Daerah menyebutkan jika "kelautan dan perikanan" menjadi urusan pemerintah daerah. Kemudian Pasal 14 UU Pemda menyebutkan bahwa "Penyelenggaraan

40 Lebih jelasnya lihat point Y Pembagian Urusan Bidang Kelautan dan Perikanan antara pemerintah pusat dan pemerintah daerah dalam Lampiran UU No 23 Tahun 2014 hlm 102. 
Urusan Pemerintahan bidang kehutanan, kelautan, serta energi dan sumber daya mineral dibagi antara Pemerintah Pusat dan Daerah provinsi." Jadi isu pesisir dan pulau-pulau kecil menjadi tanggungjawab bersama antara pemerintah daerah dan pemerintah pusat. Hal ini selaras dengan Pasal 1 UU Pengelolaan Wilayah Pesisir dan PulauPulau Kecil yang memberikan tanggungjawab kepada pemerintah pusat dan pemerintah daerah dalam pelestarian lingkungan dan ekosistem pesisir dan pulaupulau kecil.

Sebagai daerah kepulauan, Pemerintah Kabupaten Kepulauan Selayar dituntut berperan serta dalam pengelolaan, pelestarian dan perlindungan wilayah pesisir dan pulau-pulau kecil. Berdasarkan penelusuran penulis, terdapat beberapa peraturan daerah yang dibuat untuk melindungi wilayah pesisir dan pulau-pulau kecil di Kab. Kepulauan Selayar. Keberadaan Perda ini sebagai bagian dari upaya pemerintah daerah dalam mengelola, melestarikan dan melindungi ekosistem hayati laut dan perairan disekitarnya.

\section{1) Perda No 5 Tahun $2012^{41}$}

Peraturan Daerah Kabupaten Kepulauan Selayar Nomor 5 Tahun 2012 tentang Rencana Tata Ruang Wilayah Kabupaten Kepulauan Selayar Tahun 2012 - 2032 mencantumkan Rencana Detail Tata Ruang Kawasan, Kawasan Lindung dan Kawasan Budidaya. Dalam Strategi Penataan Ruang, TNT dijadikan pusat destinasi pariwisata bahari andalan nasional. Perda Tata Ruang ini semakin menguatkan posisi TNT sebagai destinasi pariwisata bahari berskala nasional, sehingga dipandang mesti ditopang dengan regulasi lokal di bidang tata ruang berbasis Kawasan.

Pasal 10 : "Strategi pengembangan pusat destinasi pariwisata bahari andalan nasional sebagaimana dimaksud dalam Pasal 4 huruf $j$ terdiri atas : (a) mengembangkan ekowisata bahari di Kawasan Taka Bonerate"

\section{2) Perda No 10 Tahun $2011^{42}$}

Peraturan Daerah Kabupaten Kepulauan Selayar Nomor 10 Tahun 2011 tentang Pengelolaan Wilayah Pesisir merupakan Peraturan Daerah yang

41 Kabupaten Kepulauan Selayar, Peraturan Daerah Kabupaten Kepulauan Selayar tentang Rencana Tata Ruang Wilayah Kabupaten Kepulauan Selayar Tahun 2012 - 2032, Perda Nomor 5 Tahun 2012.

42 Kabupaten Kepulauan Selayar, Peraturan Daerah Kabupaten Kepulauan Selayar tentang Pengelolaan Wilayah Pesisir, Perda Nomor 10 Tahun 2011. 
mengadopsi sepenuhnya UU Pengelolaan Wilayah Pesisir dan Pulau-Pulau Kecil (UU WP3K No 27 Tahun 2007). Perda No 10 Tahun 2011 memasukan TNT kedalam zona pesisir dan pulau-pulau kecil yang mesti dikelola dan dilestarikan. Perda ini juga memuat; zonasi, rencana strategis, rencana zonasi, Kawasan Konservasi Perairan, Kawasan Konservasi Laut (KKL), Daerah Perlindungan Laut (DPL), dan Kawasan Konservasi laut Daerah (KKLD).

Perkembangan hukum dan kebutuhan hukum terhadap perlindungan ekosistem hayati di TNT, kedepan perlu dilakukan perbaikan terhadap Perda ini yang disesuaikan dengan UU WP3K terbaru (UU No 1 Tahun 2014), serta UU Pemda (UU No 23 Tahun 2014), khusus menyangkut isu kelautan. Hal ini penting agar ada harmonisasi dan keselarasan antara peraturan perundangundangan di tingkat pusat dan daerah.

\section{3) Perda No 7 Tahun $2011^{43}$}

Peraturan Daerah Kabupaten Kepulauan Selayar Nomor 7 Tahun 2011 Tentang Rencana Induk Pengembangan Pariwisata Kabupaten Kepulauan Selayar. Perda ini menjadikan Taman Nasional Takabonerate sebagai Kawasan Pengembangan Pariwisata II sebagai pusat unggulan wisata bahari meliputi: Kecamatan Takabonerate dan Kecamatan Bontosikuyu (Pasal 11). Perda ini khusus mengatur isu pariwisata dengan menjadikan TNT sebagai pusat unggulan wisata bahari.

\section{4) Perda No 8 Tahun $2010^{44}$}

Peraturan Daerah Kabupaten Kepulauan Selayar Nomor 8 Tahun 2010 Tentang Pengelolaan Terumbu Karang merupakan Perda yang fokus isunya terkait pelestarian terumbu karang, termasuk terumbu karang di TNT. Dalam Pasal 3 Perda ini dikemukakan jika Pengelolaan terumbu karang dilakukan dengan tujuan untuk:

a. terciptanya sistem dan mekanisme pengelolan terubu karang yang berwawasan lingkungan;

43 Kabupaten Kepulauan Selayar Peraturan Daerah Kabupaten Kepulauan Selayar Tentang Rencana Induk Pengembangan Pariwisata Kabupaten Kepulauan Selayar, Perda Nomor 7 Tahun 2011.

44 Kabupaten Kepulauan Selayar, Peraturan Daerah Kabupaten Kepulauan Selayar Tentang Pengelolaan Terumbu Karang, Perda Nomor 8 Tahun 2010 


\begin{abstract}
b. terciptanya manfaat ekonomi sumberdaya terumbu karang secara maksimal dalam rangka peningkatan kesejahteraan masyarakat;

c. terpeliharanya kelestarian fungsi-fungsi alamiah ekosistem terumbu karang agar tetap dapat menunjang pembangunan yang berkelanjutan.
\end{abstract}

\title{
5) Perda No 6 Tahun $2009^{45}$
}

Peraturan Daerah Kabupaten Kepulauan Selayar Nomor 6 Tahun 2009 tentang Perizinan Usaha Perikanan yang sebagian besar mengadopsi UU No 31 Tahun 2004 tentang Perikanan. ${ }^{46}$ Perda ini dipandang memperkuat proteksi terhadap sumberdaya alam hayati dan ekosistem laut, khususnya perikanan, di perairan sekitar Kabupaten Kepulauan Selayar, termasuk di Taman Nasional Takabonerate. Perda ini mengatur Jenis Izin Usaha Perikanan yang meliputi: (a) Izin Usaha Perikanan (IUP); (b) Surat Penangkapan Ikan (SPI); (c) Surat Izin Kapal Pengangkut Ikan (SIKPI); (d) Izin Nelayan Andon (Nelayan Pendatang); (e) Izin Pemanfaatan dan Pemasangan Rumpon;

\section{Simpulan}

Pengelolaan, pelestarian dan perlindungan hukum terhadap TNT di Kabupaten Kepulauan Selayar, Propinsi Sulawesi Selatan yang memiliki kekayaan hayati laut tak ternilai harganya sangat penting untuk dipertahankan. Hal ini tidak saja untuk mencegah dampak kerusakan yang timbul akibat berbagai faktor, namun juga berkontribusi terhadap peningkatan taraf hidup masyarakat disekitar TNT. Keberadaan sejumlah peraturan perundang-undangan, termasuk peraturan di bawahnya, yang menjadi payung hukum pengelolaan, pelestarian dan perlindungan lingkungan hidup, khususnya lingkungan ekosistem wilayah pesisir dan pulaupulau kecil di TNT perlu dijaga dan diperkuat dengan kesadaran pemerintah daerah serta peran serta masyarakat.

Khusus terhadap Peraturan Daerah Kabupaten Kepulauan Selayar Nomor 10 Tahun 2011 tentang Pengelolaan Wilayah Pesisir, kedepan perlu dilakukan perbaikan terhadap Perda ini yang disesuaikan dengan UU WP3K terbaru (UU No 1

45 Kabupaten Kepulauan Selayar, Peraturan Daerah Kabupaten Kepulauan Selayar tentang Perizinan Usaha Perikanan yang sebagian besar mengadopsi UU No 31 Tahun 2004 tentang Perikanan, Perda Nomor 6 Tahun 2009.

Telah diubah dengan UU No 45 Tahun 2009 tentang Perikanan. 
Tahun 2014), serta UU Pemda No 23 Tahun 2014, khusus menyangkut isu kelautan. Hal ini penting agar ada harmonisasi dan keselarasan antara peraturan perundangundangan di tingkat pusat dan daerah. 


\section{Daftar Pustaka}

\section{Peraturan Perundang-undangan}

Indonesia (a). Undang-Undang tentang Konservasi Sumber Daya Alam Hayati dan Ekosistemnya, UU No. 5 Tahun 1990, LN Tahun 1990 No. 49.

(b). Undang-Undang tentang Pengesahan United Nations Convention on Biological Diversity (Konvensi Perserikatan Bangsa-Bangsa Mengenai Keanekaragaman Hayati), UU No. 5 Tahun 1994.

(c). Undang-Undang tentang Pengelolaan Wilayah Pesisir dan Pulau-Pulau Kecil, UU No 27 Tahun 2007, LN No. 84 Tahun 2007, TLN No. 4793.

(d). Undang-Undang tentang Perubahan atas Undang-Undang No. 31 Tahun 2004 tentang Perikanan, UU No. 45 Tahun 2009, LN No. 154 Tahun 2009, TLN No. 5073.

(e). Undang-Undang tentang Perlindungan dan Pengelolaan Lingkungan Hidup, UU No. 32 Tahun 2009, LN No. 140 Tahun 2009, TLN No. 5059

(f). Undang-undang tentang Perubahan Atas Undang-Undang Nomor 27 Tahun 2007 Tentang Pengelolaan Wilayah Pesisir dan Pulau-Pulau Kecil, UU No. 1 Tahun 2014, LN No. 2 Tahun 2014, TLN No. 5490.

(g). Undang-Undang tentang Pemerintahan Daerah, UU No. 23 Tahun 2014. LN No. 244 Tahun 2014, TLN No. 5587.

Kabupaten Kepulauan Selayar (a). Peraturan Daerah Kabupaten Kepulauan Selayar Tentang Rencana Induk Pengembangan Pariwisata Kabupaten Kepulauan Selayar, Perda Nomor 7 Tahun 2011.

(b). Peraturan Daerah Kabupaten Kepulauan Selayar tentang Rencana

Tata Ruang Wilayah Kabupaten Kepulauan Selayar Tahun 2012 - 2032, Perda Nomor 5 Tahun 2012.

(c). Peraturan Daerah Kabupaten Kepulauan Selayar tentang Pengelolaan Wilayah Pesisir, Perda Nomor 10 Tahun 2011.

(d). Peraturan Daerah Kabupaten Kepulauan Selayar Tentang Pengelolaan

Terumbu Karang, Perda Nomor 8 Tahun 2010. 
(e). Peraturan Daerah Kabupaten Kepulauan Selayar tentang Perizinan Usaha Perikanan yang sebagian besar mengadopsi UU No 31 Tahun 2004 tentang Perikanan, Perda Nomor 6 Tahun 2009.

Mahkamah Konstitusi, Putusan Mahkamah Konstitusi Nomor 3/PUU-VIII/2010.

United Nations, Convention on Biological Diversity, Rio de Jeneiro, 5 June 1992. Dapat dibuka di: https://treaties.un.org/pages/ViewDetails. aspx?src=TREATY\&mtdsg_no=XXVII-8\&chapter $=27 \&$ lang $=$ en

\section{Buku}

Asshidiqie, Jimly, Green Constitution: Nuansa Hijau Undang-Undang Dasar, Jakarta: Rajawali Pers, 2009.

Asep Sugiharta (Kepala Unit Pengelolaan Taman Nasional Taka Bonerate). "Prospek dan Kontribusi Taman Nasional Taka Bonrate Terhadap pembangunan Daerah", Disampaikan dalam Pertemuan Regional Pengelolaan Taman Nasional Kawasan Timur Indonesia, Kelembagaan Pengelolaan Taman Nasional, Manado, 24-27 Agustus 1999.

Sudirman, Warning Atas Kerusakan Hutan Bawah Laut, Fakultas Ilmu Kelautan dan Perikanan Unhas (tanpa tahun).

"Konflik Laut China Selatan dan Implikasinya Terhadap Kawasan," Diterbitkan oleh P3DI Setjen DPR Republik Indonesia dan Azza Grafika, Jakarta: 2013.

Menggugat Negara: Rasionalitas Demokrasi, HAM dan Kebebasan. Jakarta: PBHI dan European Union (UE), 2005.

Satijipto Raharjo, Ilmu Hukum, Bandung : PT. Citra Aditya Bakti, 2000.

Siti Sundari Rangkuti, Hukum Lingkungan dan Kebijaksanaan Lingkungan Nasional, Edisi Ketiga, (Surabaya: Airlangga University Press, 2005), hlm 353.

Strategi Utama Jejaring Kawasan Konservasi Laut; Program Rehabilitasi dan Pengelolaan Terumbu Karang Tahap II (COREMAP II), Direktorat Jenderal Kelautan, Pesisir dan Pulau-Pulau Kecil, Departemen Kelautan dan Perikanan RI, 2006. 